\title{
Preferensi Pemilihan Moda Transportasi Siswa Sebelum dan Sesudah Pemberlakuan Kebijakan Zonasi Layanan Pendidikan
}

\author{
Sri Lestari dan Dewanti \\ Magister Perencanaan Wilayah dan Kota, Fakultas Teknik, Universitas Gadjah Mada \\ e-mail: srilestari90@mail.ugm.ac.id dandewanti@ugm.ac.id
}

\begin{abstract}
Abstrak-Kebijakan zonasi layanan pendidikan dapat memperpendek jarak perjalanan ke sekolah dan biaya perjalanan. Pengurangan jarak perjalanan dan biaya perjalanan akan memengaruhi pemilihan moda transportasi. Dengan adanya pilihan moda transportasi yang beragam, diharapkan penggunaan moda transportasi nonmotor menjadi lebih dominan sehingga dapat mengurangi kemacetan lalu lintas dan dapat mendukung terwujudnya kota yang layak huni. Penelitian ini bertujuan untuk membandingkan preferensi pemilihan moda transportasi siswa sebelum dan sesudah pemberlakuan kebijakan zonasi layanan pendidikan. Responden penelitian ini adalah siswa kelas 7 dan kelas 9 SMP. Siswa kelas 7 sebagai sampel siswa yang diberlakukan kebijakan zonasi pada saat proses penerimaannya, dan siswa kelas 9 sebagai sampel siswa yang tidak diberlakukan kebijakan zonasi pada saat proses penerimaannya. Jumlah responden penelitian ini sebanyak 377 siswa. Jenis data yang digunakan di dalam penelitian ini adalah data kuantitatif dari kuesioner dan data kualitatif dari wawancara sebagai data pendukung. Penelitian ini menggunakan analisis spasial untuk menjelaskan preferensi pemilihan moda transportasi dengan menggunakan peta. Analisis crosstab dan analisis deskriptif dari wawancara digunakan untuk mengidentifikasi faktorfaktor yang memengaruhi pemilihan moda transportasi. Kebijakan zonasi layanan pendidikan tidak berpengaruh terhadap preferensi pemilihan moda transportasi siswa. Sepeda motor mendominasi preferensi pemilihan moda transportasi siswa sebelum dan sesudah pemberlakuan kebijakan zonasi. Preferensi pemilihan moda transportasi siswa di sekolah tengah kota dan di pinggiran kota juga didominasi diantar dengan sepeda motor. Preferensi pemilihan moda transportasi di Kota Surakarta dipengaruhi oleh faktor internal individu dan faktor eksternal individu.
\end{abstract}

Kata Kunci-Crosstab, Kebijakan Zonasi Layanan Pendidikan, Pemilihan Moda Transportasi, Preferensi.

\section{PENDAHULUAN}

$\mathrm{T}$ INGGINYA penggunaan kendaraan pribadi menuju sekolah turut menyumbang terjadinya kepadatan lalu lintas jam sibuk pagi dan sore hari. Tingginya penggunaan kendaraan pribadi dapat menyebabkan kemacetan, peningkatan polusi dan penurunan tingkat kenyamanan masyarakat dalam beraktivitas. Kemacetan dapat menurunkan kualitas hidup masyarakat sehingga konsep livable city (kota layak huni) di Kota Surakarta tidak dapat terwujud.

Konsep livable city atau kota layak huni menggambarkan kota yang nyaman untuk mendukung aktivitas masyarakat di dalamnya menuju kesejahteraan atau peningkatan kualitas hidup. Kota layak huni dapat diwujudkan dengan cara memberikan kemudahan akses pelayanan umum, memberikan rasa aman pada pejalan kaki dan pesepeda, menyediakan perumahan yang terjangkau dan ramah pendatang, penghematan biaya transportasi yang dikeluarkan masyarakat, meningkatkan aksesibilitas, meningkatkan citra kawasan, dan menjaga kelestarian lingkungan [8].

Lokasi SMP dan MTs di Kota Surakarta sudah dapat menjangkau semua wilayah kelurahan dengan jarak tempuh maksimal 6 km. Namun, menurut SNI 03-1733-2004 tentang Tata Cara Perencanaan Lingkungan Perumahan di Perkotaan, radius pencapaian SMP seharusnya $1 \mathrm{~km}$. Hal ini berarti bahwa radius pelayanan fasilitas SMP di Kota Surakarta belum sesuai dengan SNI [19].

Zonasi layanan pendidikan ditetapkan dalam rangka meningkatkan akses terhadap layanan pendidikan tanpa diskriminasi. Pemerintah Kota Surakarta membuat kebijakan zonasi layanan pendidikan melalui aplikasi PPDB Online sesuai dengan Peraturan Walikota Surakarta Nomor 17 Tahun 2019 tentang Penerimaan Peserta Didik Baru pada Taman Kanak-Kanak, Sekolah Dasar, dan Sekolah Menengah Pertama dan Surat Keputusan Kepala Dinas Pendidikan Kota Surakarta Nomor 954/1095.3/KEP/SET/2019 tentang Petunjuk Teknis Penyelenggaraan Penerimaan Peserta Didik Baru (PPDB) Kota Surakarta Tahun Pelajaran 2019/2020 sebagai pedoman teknisnya. Penerimaan peserta didik baru dilaksanakan dengan tiga jalur yaitu jalur zonasi (kuota 90\%), jalur prestasi (kuota 5\%), dan jalur perpindahan tugas orang tua/wali (5\%). Kebijakan zonasi yang diterapkan yaitu penerimaan siswa baru dengan berdasar kepada kedekatan koordinat RT tempat tinggal sesuai data administrasi kependudukan dengan koordinat sekolah. Melalui aplikasi PPDB Online, calon siswa diarahkan untuk mendaftar di sekolah terdekat dengan tempat tinggalnya. Sebelum ada kebijakan ini, siswa bisa memilih sekolah sesuai dengan keinginan dan popularitas sekolahnya. Namun, dengan kebijakan ini, siswa hanya bisa memilih sekolah yang terdekat dengan tempat tinggalnya.

Proses implementasi dan efektivita kebijakan zonasi layanan pendidikan memeratakan akses dan mutu pendidikan. Kebijakan zonasi layanan pendidikan berpengaruh terhadap prestasi belajar siswa [20]. Kebijakan zonasi layanan pendidikan berpengaruh terhadap pemerataan mutu pendidikan [10] [11]. Ditinjau dari aspek hukum, efektivitas peraturan terkait kebijakan zonasi layanan pendidikan dinilai kurang efektif [13][17]. Kebijakan zonasi layanan pendidikan berpengaruh dalam 
pembentukan karakter siswa [4].

Permasalahan-permasalahan yang terjadi beserta faktor pendukung dan penghambat pelaksanaan kebijakan. Di dalam implementasi kebijakan zonasi layanan sekolah, perlu adanya penguatan peran lembaga pengawasan [5]. Kebijakan zonasi layanan sekolah belum efektif dalam menghilangkan label "sekolah favorit" di masyarakat [7]. Faktor yang menghambat implementasi kebijakan zonasi layanan pendidikan yaitu sumber daya, pelaksana kebijakan, dan tingkat kepatuhan [9]. Kurangnya pemerataan persebaran dan fasilitas sekolah juga menimbulkan konflik sehingga menghambat pelaksanaan kebijakan [18]. Dalam pelaksanaan kebijakan pun juga ditemukan maladministrasi seperti kelalaian, nepotisme, kolusi, dan intervensi pejabat publik [12]. Dibutuhkan sosialisasi terkait kebijakan zonasi layanan pendidikan yang menjangkau seluruh elemen masyarakat [16]. Berdasarkan penelitian-penelitian tersebut, diperoleh hasil bahwa kebijakan zonasi layanan pendidikan kurang efektif karena penyediaan fasilitas pendidikan dan ketersediaan guru yang tidak merata di setiap daerah. Sementara itu, penelitian terkait dampak kebijakan zonasi layanan pendidikan terkait aspek spasial dan transportasi belum banyak dilakukan. Pengurangan jarak perjalanan akibat adanya kebijakan zonasi layanan pendidikan memungkinkan penggunaan sepeda dan berjalan kaki menjadi lebih dominan karena jarak antara tempat tinggal menuju sekolah menjadi lebih pendek [14] sedangkan alternatif pemilihan moda pada umumnya berdasarkan pada jarak dan waktu tempuh perjalanan [6].

Preferensi merupakan kecenderungan seorang mengambil keputusan terhadap pilihan suatu hal. Preferensi konsumen berkaitan dengan sikap suka atau tidak suka seorang konsumen terhadap barang dan jasa. Perilaku konsumen yaitu perilaku yang terlihat saat konsumen di dalam proses mencari, menyeleksi, dan memilih menggunakan atau tidak menggunakan barang atau jasa untuk memuaskan kebutuhannya [3]. Hal ini termasuk juga dalam keputusan seseorang dalam memilih moda transportasi, keputusan menggunakan atau tidak menggunakan moda tertentu. Variabel-variabel yang memengaruhi preferensi dalam memilih moda transportasi terbagi menjadi faktor karakteristik perjalanan, karakteristik pelaku perjalanan, karakteristik sistem transportasi, serta karakteristik kota dan zona [15].

Dinas Pendidikan Kota Surakarta menyampaikan bahwa kebijakan zonasi layanan pendidikan dapat mendorong siswa untuk berjalan kaki saat berangkat dan pulang sekolah karena lokasi sekolahnya dekat sehingga siswa tidak perlu diantar dengan kendaraan bermotor. Jarak jangkauan layanan pendidikan SMP di Kota Surakarta yang tidak sesuai dengan SNI dan berbagai macam alternatif pilihan moda yang ada memungkinkan penggunaan moda transportasi menuju sekolah yang beragam dan dikhawatirkan harapan pengurangan kendaraan bermotor ke sekolah tidak dapat terwujud. Penelitian ini dilakukan untuk mengkaji hubungan kebijakan zonasi layanan pendidikan terhadap pemilihan moda transportasi siswa ke sekolah.
Penelitian ini bertujuan untuk:

1. menjelaskan preferensi pemilihan moda transportasi siswa dari tempat tinggal menuju sekolah saat sebelum dan sesudah diberlakukannya kebijakan zonasi layanan pendidikan dan

2. mengidentifikasi faktor-faktor yang memengaruhi pemilihan moda transportasi siswa saat sebelum dan sesudah diberlakukannya kebijakan zonasi layanan pendidikan.

\section{METODE PENELITIAN}

Penelitian ini menggunakan pendekatan deduktif. Di dalam penelitian ini, digunakanlah metode penelitian kombinasi (mixed methods) yaitu gabungan antara metode penelitian kuantitatif dan metode penelitian kualitatif. Metode penelitian kombinasi di penelitian ini digunakan untuk membuktikan teori pemilihan moda transportasi dan untuk menjelaskan teori perilaku konsumen dalam kasus pemilihan moda transportasi siswa ke sekolah.

Untuk tujuan penelitian pertama terkait preferensi pemilihan moda transportasi, dilakukan pendekatan kuantitatif yaitu dengan analisis statistik deskriptif dan analisis spasial. Analisis spasial dilakukan untuk menjelaskan preferensi pemilihan moda transportasi siswa dengan menggunakan peta. Kemudian untuk tujuan penelitian kedua terkait faktor-faktor yang memengaruhi pemilihan moda transportasi siswa dilakukan dengan kombinasi (mixed methods) yaitu dengan metode kuantitatif analisis statistik crosstab dan metode kualitatif analisis deskriptif dari hasil wawancara sebagai data pendukungnya.

Ada tidaknya hubungan secara statistik antara variabel bebas dengan pemilihan moda transportasi diketahui dengan melakukan analisis crosstab. Variabel yang disilangkan yaitu preferensi pemilihan moda dengan variabel bebas berjumlah 32 variabel yaitu waktu perjalanan, biaya perjalanan, jarak tempuh perjalanan, jenis kelamin, usia, kepemilikan kendaraan orang tua, pekerjaan orang tua, pendapatan orang tua, besarnya uang saku, ketersediaan angkutan umum, keandalan angkutan umum, kemudahan akses angkutan umum, kemudahan akses angkutan online, keandalan angkutan online, ketersediaan parkir khusus sepeda, ketersediaan jalur khusus sepeda, ketersediaan trotoar/jalur pejalan kaki, kenyamanan angkutan umum, kenyamanan di jalur sepeda, kenyamanan jalur pejalan kaki, kenyamanan angkutan online, keamanan di angkutan umum, keamanan di jalur pejalan kaki, keamanan di jalur sepeda, keamanan di angkutan online, ketersediaan tempat penyeberangan, ketersediaan marka jalur pejalan kaki, ketersediaan marka jalur sepeda, jaminan keselamatan di angkutan umum, jaminan keselamatan di angkutan online, arahan dari orang tua, dan arahan dari pihak sekolah. 
Penelitian ini menggunakan siswa SMP negeri (SMPN) sebagai responden karena kebijakan zonasi layanan pendidikan hanya diterapkan di sekolah negeri. Kebijakan zonasi layanan pendidikan yang menerapkan skema jarak dengan koordinat memungkinkan diperoleh sampel dengan jarak tempat tinggal yang variatif dari jarak yang sangat dekat hingga jarak yang sangat jauh. Selain itu, siswa SMP dipilih karena pelajar SMP sudah berada pada usia remaja yang memungkinkan lebih mudah dalam memberikan informasi. Siswa pada rentang usia SMP sudah memiliki kemandirian melakukan aktivitas namun masih mendapat pengaruh dari orang tua.

Preferensi pemilihan moda transportasi siswa dianalisis dengan membandingkan kondisi sebelum diberlakukannya kebijakan zonasi layanan pendidikan dan sesudah diberlakukannya kebijakan zonasi layanan pendidikan pada saat proses penerimaannya, yaitu membandingkan antara siswa yang diberlakukan kebijakan zonasi pada saat proses penerimaannya yaitu siswa kelas 7 dan siswa yang tidak diberlakukan kebijakan zonasi pada saat proses penerimaannya yaitu siswa kelas 9 .

Karakteristik pola perjalanan penduduk di wilayah pinggiran berbeda dengan di wilayah pusat kota. Dengan karakteristik pola perjalanan yang berbeda, maka preferensi pemilihan moda transportasi juga berbeda [15]. Oleh karena itu, lokasi penelitian berada di 14 SMPN di Kota Surakarta yang tersebar di tengah kota dan di pinggiran kota. Pemilihan sekolah tersebut dimaksudkan untuk mengetahui perbedaan preferensi pemilihan moda transportasi siswa di wilayah pinggiran kota dan wilayah pusat kota. Lokasi penelitian antara lain:

1. sekolah di pinggiran kota: SMPN 2 Surakarta, SMPN 8 Surakarta, SMPN 9 Surakarta, SMPN 11 Surakarta, SMPN 18 Surakarta, SMPN 19 Surakarta, SMPN 22 Surakarta, dan SMPN 27 Surakarta serta

2. sekolah di tengah kota: SMPN 1 Surakarta, SMPN 10 Surakarta, SMPN 13 Surakarta, SMPN 15 Surakarta, SMPN 24 Surakarta, dan SMPN 25 Surakarta.

Populasi di dalam penelitian ini adalah semua siswa kelas 7 dan 9 berjumlah 6.346 orang. Metode pengambilan sampel yang digunakan adalah proportional sampling. Teknik pengambilan sampel dengan cara simple random sampling kemudian diproporsikan untuk masing-masing lokasi sekolah. Jumlah sampel dihitung dengan menggunakan rumus Bungin [2] sebanyak 377 responden. Rincian proporsi sampel dapat dilihat di Tabel 1.

Sebagai data pendukung untuk mengklarifikasi hasil kuesioner, dilakukan wawancara kepada responden. Wawancara dilakukan secara tidak terstruktur dan dilakukan secara bersama-sama pada saat penyebaran kuesioner. Penentuan narasumber yang diwawancara dilakukan dengan metode accidental sampling. Namun, terjadinya pandemi Covid-19 pada saat proses pengumpulan data menyebabkan peneliti terkendala waktu yang terbatas sehingga wawancara yang dilakukan menjadi kurang maksimal. Dari 377 responden tersebut, hanya bisa didapatkan 16 orang siswa yang bersedia diwawancarai. Narasumber dalam wawancara yaitu ARG (siswa kelas 7 SMPN 1 Surakarta), CEH (siswa kelas 7 SMPN 1 Surakarta), Y (siswa kelas 7 SMPN 11 Surakarta), INA (siswa kelas 7 SMPN 13 Surakarta), NKAA (siswa kelas 7 SMPN 18 Surakarta), NVA (siswa kelas 7
SMPN 19 Surakarta), SOA (siswa kelas 7 SMPN 2 Surakarta), VNC (siswa kelas 7 SMPN 22 Surakarta), RAA (siswa kelas 9 SMPN 1 Surakarta), ARF (siswa kelas 9 SMPN 13 Surakarta), F (siswa kelas 9 SMPN 18 Surakarta), AFW (siswa kelas 9 SMPN 8 Surakarta), DYRI (siswa kelas 9 SMPN 9 Surakarta), AA (siswa kelas 9 SMPN 10 Surakarta), IHA (siswa kelas 9 SMPN 18 Surakarta), dan AB (siswa kelas 9 SMPN 24 Surakarta).

\section{HASIL DAN DISKUSI}

\section{A. Preferensi Pemilihan Moda Transportasi Siswa}

Berdasarkan hasil survei lapangan diperoleh tiga pola Tabel 1.

Rincian Proporsi Sampel

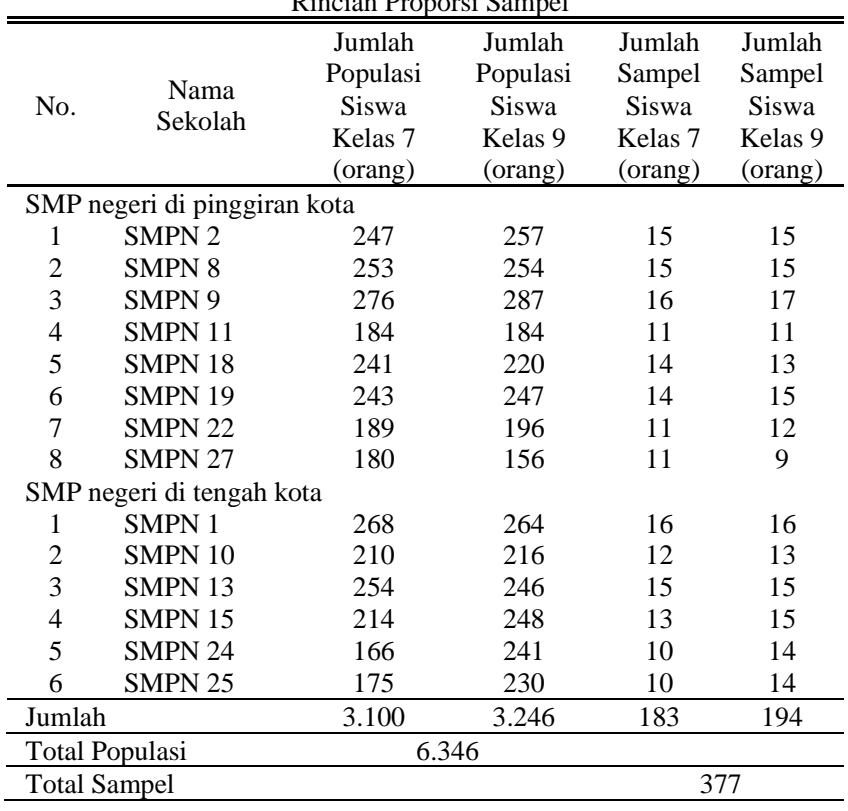

pergerakan siswa dalam perjalanan pendidikan yaitu:

1. berangkat dari rumah menuju sekolah kemudian pulang langsung ke rumah. Siswa berangkat sendiri ataupun diantar orang tua ke sekolah sedangkan untuk perjalanan pulang siswa pulang sendiri ataupun dijemput orang tua dan langsung menuju ke rumah tanpa singgah ke tujuan yang lain. Persentase pola pergerakan ini sebesar $97,08 \%$;

2. berangkat dari rumah menuju sekolah lalu pulang berjalan kaki ke rumah saudara baru kemudian pulang dijemput atau dengan memesan angkutan online menuju rumah. Siswa berangkat sendiri ataupun diantar orang tua ke sekolah, sedangkan untuk perjalanan pulang siswa singgah dulu ke rumah saudara yang berada di dekat sekolah baru kemudian pulang ke rumah sendiri ataupun dijemput orang tua. Persentase pola pergerakan ini sebesar $0,53 \%$; serta

3. Berangkat dari rumah menuju sekolah, lalu untuk perjalanan pulang dijemput dengan berbarengan menjemput anggota keluarga yang lain baru kemudian pulang ke rumah. Perjalanan berangkat dan pulang siswa sekalian perjalanan bekerja orang tua. Persentase pola pergerakan ini sebesar 2,39\%.

Berdasarkan hasil survei dari keseluruhan sampel terdapat perbedaan moda transportasi siswa pada saat berangkat dan pulang sekolah sebesar $18 \%$. Perbedaan moda 
antara berangkat dan pulang sekolah sebagian besar disebabkan karena orang tua yang tidak bisa menjemput/mengantar. Sebagian besar siswa diantar orang tua dengan motor. Penggunaan moda transportasi siswa kelas 9 didominasi dengan diantar orang tua dengan sepeda motor dan sepeda, untuk siswa kelas 7 didominasi dengan diantar orang tua dengan sepeda motor, sepeda, dan berjalan kaki. Dominasi penggunaan sepeda motor ke sekolah dengan diantar orang tua mencerminkan pengambilan keputusan mayoritas siswa memilih moda transportasi yang digunakan masih bergantung kepada orang tua. Hal ini disebabkan siswa SMP belum cukup umur untuk menggunakan kendaraan bermotor sendiri karena belum bisa mendapatkan SIM.

\section{B. Jarak Tempuh Perjalanan Siswa pada Saat Sebelum dan Sesudah Adanya Kebijakan Zonasi Layanan Pendidikan}

Jarak perjalanan siswa dari rumah menuju sekolah digambarkan secara spasial sesuai dengan Surat Keputusan Kepala Dinas Pendidikan Kota Surakarta Nomor 954/1095.3/KEP/SET/2019 tentang Petunjuk Teknis Penyelenggaraan Penerimaan Peserrta Didik Baru (PPDB) Kota Surakarta Tahun Pelajaran 2019/2020, yaitu dengan berdasar pada kedekatan koordinat RT tempat tinggal sesuai data administrasi kependudukan dengan koordinat sekolah. Secara spasial digambarkan dengan menghubungkan titik koordinat RT tempat tinggal siswa dengan titik koordinat sekolah sehingga diperoleh jarak tempuh perjalanan siswa.

Terdapat perbedaan signifikan rata-rata jarak tempat tinggal siswa pada saat sebelum dan sesudah pemberlakuan kebijakan zonasi layanan pendidikan, yaitu dari $3,72 \mathrm{~km}$ menjadi $1,44 \mathrm{~km}$. Perbandingan preferensi pemilihan moda transportasi siswa pada saat sebelum dan sesudah adanya kebijakan zonasi secara rinci dapat dilihat di Gambar 1 dan Gambar 2. Di Gambar 1, dapat dilihat bahwa pada saat sebelum adanya kebijakan zonasi layanan pendidikan, preferensi pemilihan moda transportasi siswa didominasi oleh diantar orang tua dengan sepeda motor sebesar $71 \%$ dan sepeda sebesar $11 \%$. Sedangkan pada saat sesudah adanya kebijakan zonasi layanan pendidikan, preferensi pemilihan moda transportasi siswa didominasi oleh diantar orang tua dengan sepeda motor sebesar $67 \%$, sepeda sebesar $17 \%$, dan berjalan kaki sebesar $11 \%$. Pemilihan moda sepeda dan berjalan kaki pada saat sesudah adanya kebijakan zonasi lebih besar pada saat sebelum adanya kebijakan zonasi. Hal ini dimungkinkan karena jarak perjalanan pada saat sesudah adanya kebijakan zonasi menjadi lebih pendek. Pemilihan moda bus/angkutan umum dan naik motor sendiri tidak ditemukan pada saat sesudah adanya kebijakan zonasi (siswa kelas 7). Hal ini dimungkinkan karena faktor usia siswa dan kekhawatiran orang tua siswa.

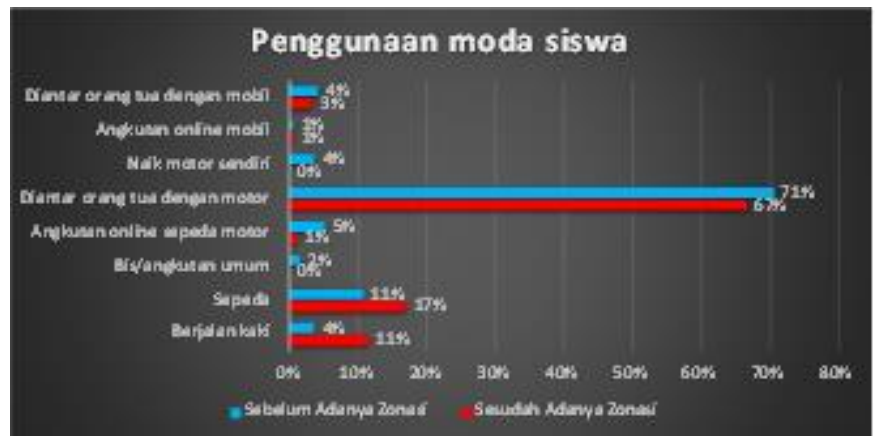

Gambar 1. Perbandingan Penggunaan Moda Transportasi Siswa pada Saat Sebelum dan Sesudah Adanya Kebijakan Zonasi Layanan Pendidikan.

Secara spasial, perbandingan penggunaan moda transportasi siswa pada saat sebelum dan sesudah adanya kebijakan zonasi layanan pendidikan dapat dilihat di Gambar 2. Peta menunjukkan gambaran spasial panjang perjalanan siswa dari rumah menuju ke sekolah yang dibedakan berdasarkan penggunaan moda transportasinya. Pada Gambar 2 dapat dilihat bahwa dominasi penggunaan moda transportasi siswa pada saat sebelum adanya kebijakan zonasi layanan pendidikan (siswa kelas 9) dan pada saat sesudah adanya kebijakan zonasi layanan pendidikan (siswa kelas 7) adalah diantar orang tua dengan menggunakan sepeda motor. Panjang perjalanan siswa pada saat sesudah adanya kebijakan zonasi layanan pendidikan lebih pendek daripada panjang perjalanan siswa pada saat sebelum adanya kebijakan zonasi layanan pendidikan. 


\section{Sebelum Adanya Zon asi}

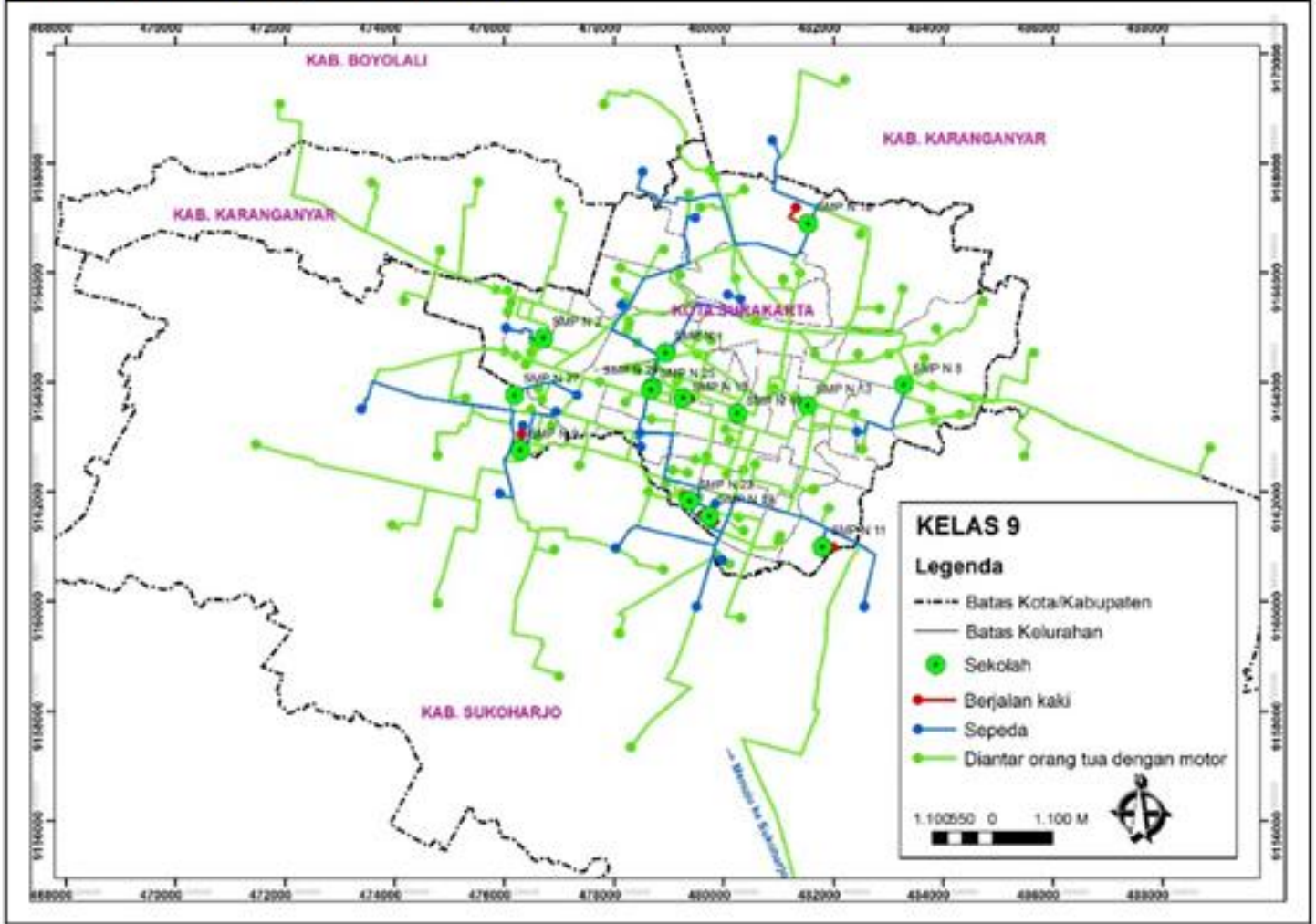

\section{Sesud ah Ad anya Zonasi}

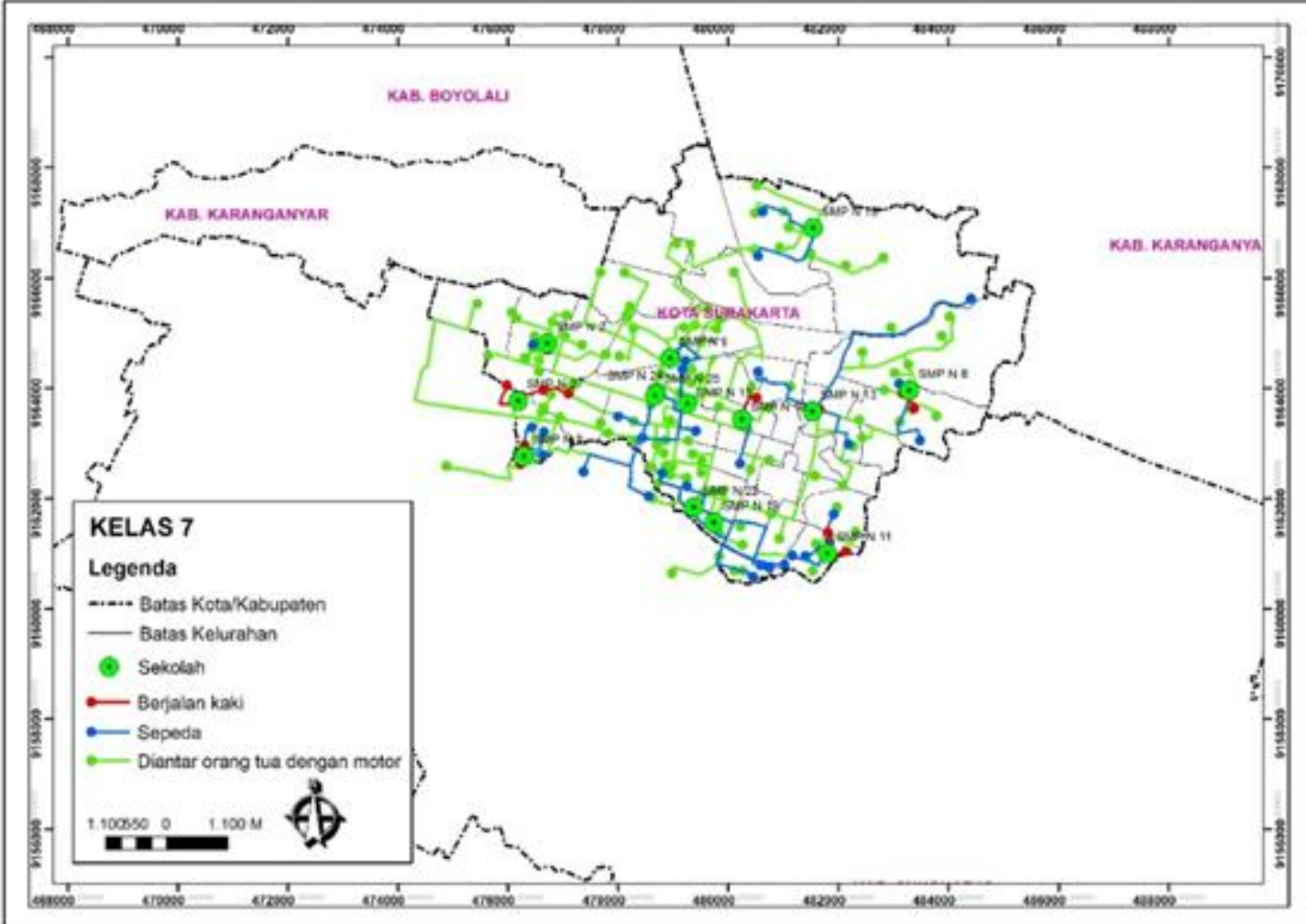

Gambar 2. Perbandingan Preferensi Pemilihan Moda Transportasi Siswa pada Saat Sebelum dan Sesudah Adanya Kebijakan Zonasi Layanan Pendidikan. 
Tabel 2

Perbandingan Jarak Rata-Rata Pemilihan Moda Transportasi Siswa pada Saat Sebelum dan Sesudah Adanya Kebijakan Zonasi

\begin{tabular}{|c|c|c|c|c|c|c|c|}
\hline \multirow{2}{*}{ No. } & \multirow{2}{*}{ Moda Transportasi } & \multicolumn{3}{|c|}{ Sebelum Adanya Zonasi } & \multicolumn{3}{|c|}{ Sesudah Adanya Zonasi } \\
\hline & & $\begin{array}{l}\text { Jarak minimal } \\
\qquad(\mathrm{km})\end{array}$ & $\begin{array}{c}\text { Jarak maksimal } \\
(\mathrm{km})\end{array}$ & $\begin{array}{c}\text { Jarak rata-rata } \\
(\mathrm{km})\end{array}$ & $\begin{array}{l}\text { Jarak minimal } \\
\qquad(\mathrm{km})\end{array}$ & $\begin{array}{c}\text { Jarak maksimal } \\
(\mathrm{km})\end{array}$ & $\begin{array}{c}\text { Jarak rata-rata } \\
(\mathrm{km})\end{array}$ \\
\hline 1 & Berjalan kaki & 0,238 & 0,812 & 0,39 & 0,099 & 1,137 & 0,0193233 \\
\hline 2 & Sepeda & 0,550 & 4,915 & 2,41 & 0,264 & 4,186 & 0,0132334 \\
\hline 3 & Bis/angkutan umum & 1,894 & 31,098 & 13,85 & - & - & 0,0132334 \\
\hline 4 & Sepeda motor & 0,216 & 19,652 & 3,71 & 0,090 & 5,496 & 0,2343343 \\
\hline 5 & Mobil & 1,502 & 17,587 & 6,20 & 0,548 & 2,902 & 0,0234443 \\
\hline
\end{tabular}

Pada Tabel 2, dihasilkan alternatif pemilihan moda untuk perjalanan jarak dekat $(0,4 \mathrm{~km})$ ditempuh dengan berjalan kaki, untuk perjalanan jarak dekat $(1-2 \mathrm{~km})$ ditempuh dengan alternatif moda sepeda atau sepeda motor, untuk perjalanan jarak sedang $(3-5 \mathrm{~km})$ ditempuh dengan alternatif moda mobil, sedangkan moda bus/angkutan umum digunakan untuk perjalanan jarak jauh (lebih dari $10 \mathrm{~km}$ ).

\section{Jangkauan Pelayanan Fasilitas Pendidikan pada Saat Sebelum dan Sesudah Adanya Kebijakan Zonasi Layanan Pendidikan}

Sesuai dengan SNI 03-1733-2004 tentang Tata Cara Perencanaan Lingkungan Perumahan di Perkotaan, standar pelayanan minimal pelayanan fasilitas pendidikan tingkat SMP adalah pada jangkauan radius $1.000 \mathrm{~m}$ [1]. Jarak pelayanan fasilitas pendidikan digambarkan secara spasial sesuai dengan SNI 03-1733-2004, yaitu dengan menarik garis radius $1.000 \mathrm{~m}$ dari titik koordinat sekolah. Kemudian area jangkauan pelayanan tersebut dibandingkan dengan jarak tempuh perjalanan siswa dari rumah menuju ke sekolah.

Pada saat sebelum adanya kebijakan zonasi, jangkauan pelayanan fasilitas pendidikan tidak memenuhi standar pelayanan minimal tersebut. Pada saat sesudah adanya kebijakan zonasi, jangkauan pelayanan fasilitas pendidikan mendekati standar pelayanan minimal tersebut. Perbandingan jangkauan pelayanan fasilitas pendidikan pada saat sebelum dan sesudah pemberlakuan kebijakan zonasi layanan pendidikan untuk sekolah di pinggiran kota dan sekolah di tengah kota ditampilkan pada Gambar 3 dan Gambar 4.

Secara spasial, jangkauan pelayanan sekolah di tengah kota pada saat sebelum dan sesudah adanya kebijakan zonasi layanan pendidikan dibandingkan dengan SNI dapat dilihat pada Gambar 3. Dari Gambar 3, dapat diketahui bahwa jangkauan layanan pendidikan SMP di tengah kota, baik sebelum dan sesudah adanya kebijakan zonasi layanan pendidikan, masih belum sesuai dengan SNI yaitu radius $1.000 \mathrm{~m}$. Pada sekolah di tengah kota, sebelum adanya kebijakan zonasi, jangkauan fasilitas pendidikan rata-rata 3,264 km. Pada saat sesudah adanya kebijakan zonasi, panjang perjalanan siswa menjadi lebih pendek yaitu ratarata $1,195 \mathrm{~km}$ meski jangkauannya masih tidak sesuai SNI. Hal ini disebabkan lokasi sekolah yang tidak berdekatan dengan kawasan permukiman, jarak antarsekolah yang terlalu dekat, dan daya tampung sekolah masih tersedia untuk menampung siswa dari tempat tinggal yang lebih jauh.

Secara spasial, jangkauan pelayanan sekolah di pinggiran kota pada saat sebelum dan sesudah adanya kebijakan zonasi layanan pendidikan dibandingkan dengan SNI dapat dilihat di Gambar 4. Dari Gambar 4, dapat diketahui bahwa jangkauan layanan pendidikan SMP di pinggiran kota, baik sebelum dan sesudah adanya kebijakan zonasi layanan pendidikan, juga belum sesuai dengan SNI yaitu radius $1.000 \mathrm{~m}$. Pada sekolah di pinggiran kota, saat sebelum adanya kebijakan zonasi, jangkauan fasilitas pendidikan rata-rata 4,286 km. Pada saat sesudah adanya kebijakan zonasi, rata-rata jarak perjalanan berkurang signifikan menjadi 1,776 km meski masih ditemukan sekolah yang tidak sesuai SNI, yaitu SMPN 18 Surakarta, SMPN 19 Surakarta, dan SMPN 22 Surakarta. Hal ini disebabkan jarak antarsekolah berdekatan dengan sekolah lain dan daya tampung sekolah masih tersedia untuk menampung siswa dari tempat tinggal yang lebih jauh. 


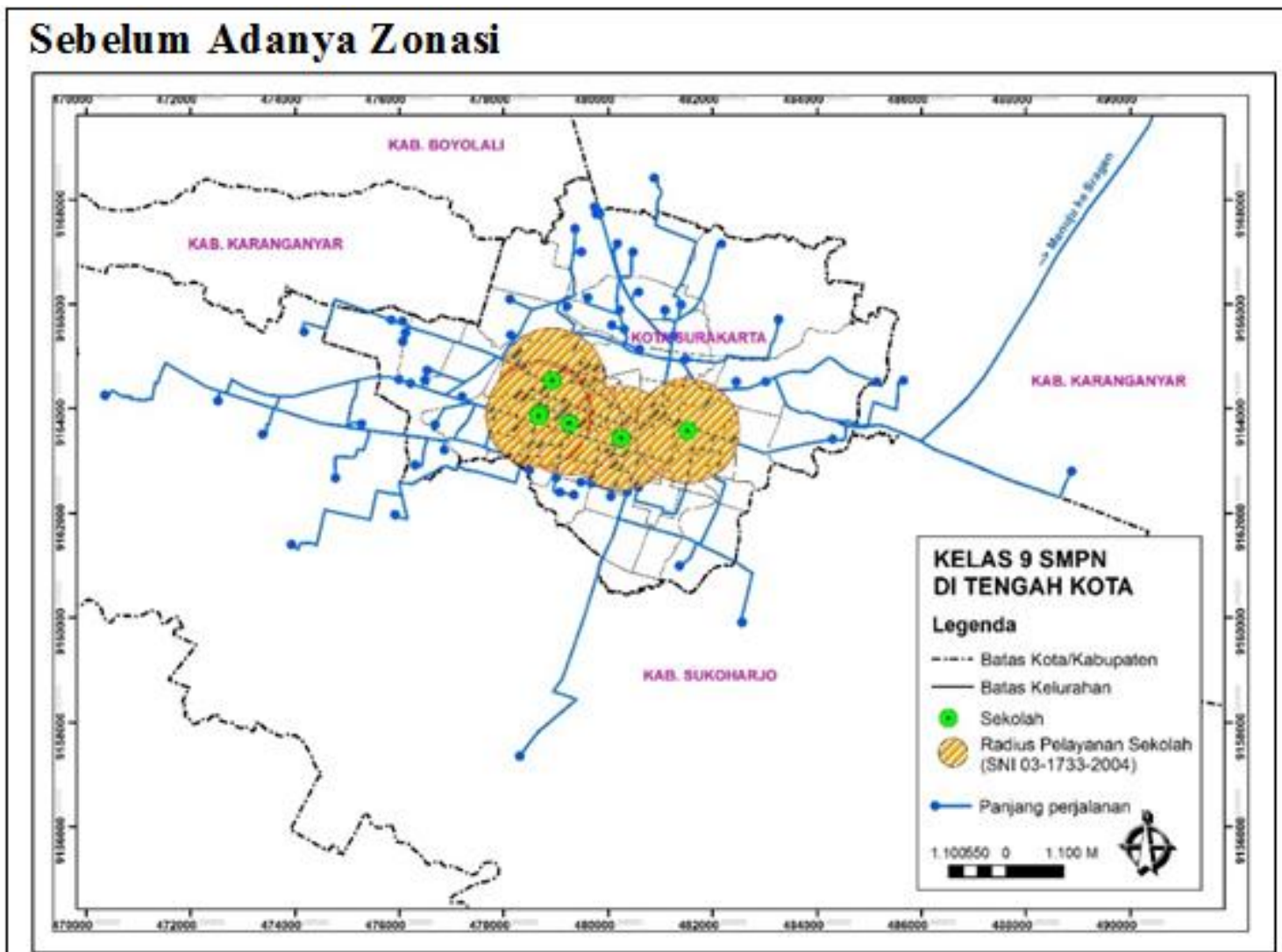

\section{Sesu dah Adanya Zonasi}

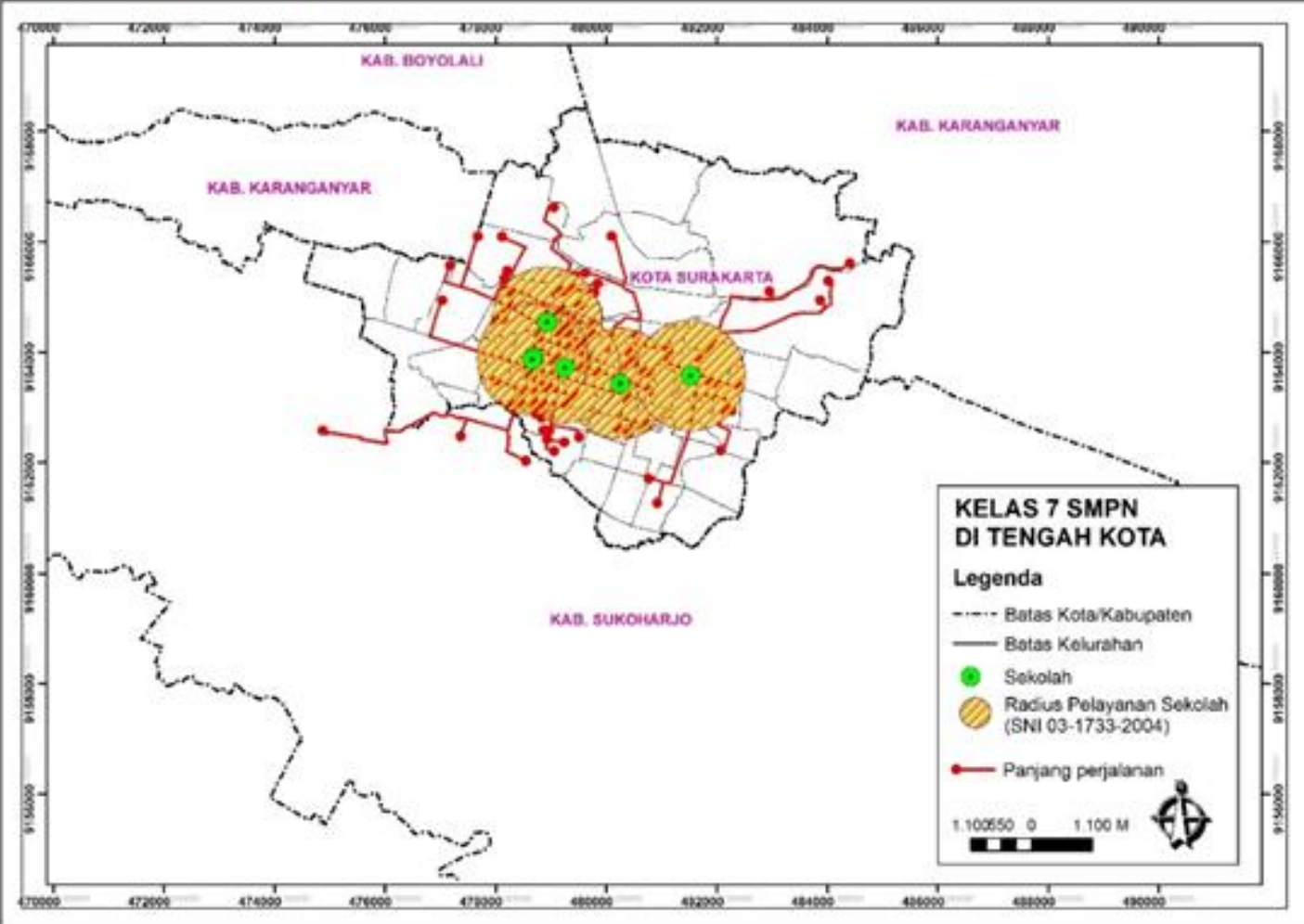

Gambar 3. Perbandingan Jangkauan Pelayanan Fasilitas Pendidikan pada Saat Sebelum dan Sesudah Adanya Kebijakan Zonasi Layanan Pendidikan di Sekolah Tengah Kota. 


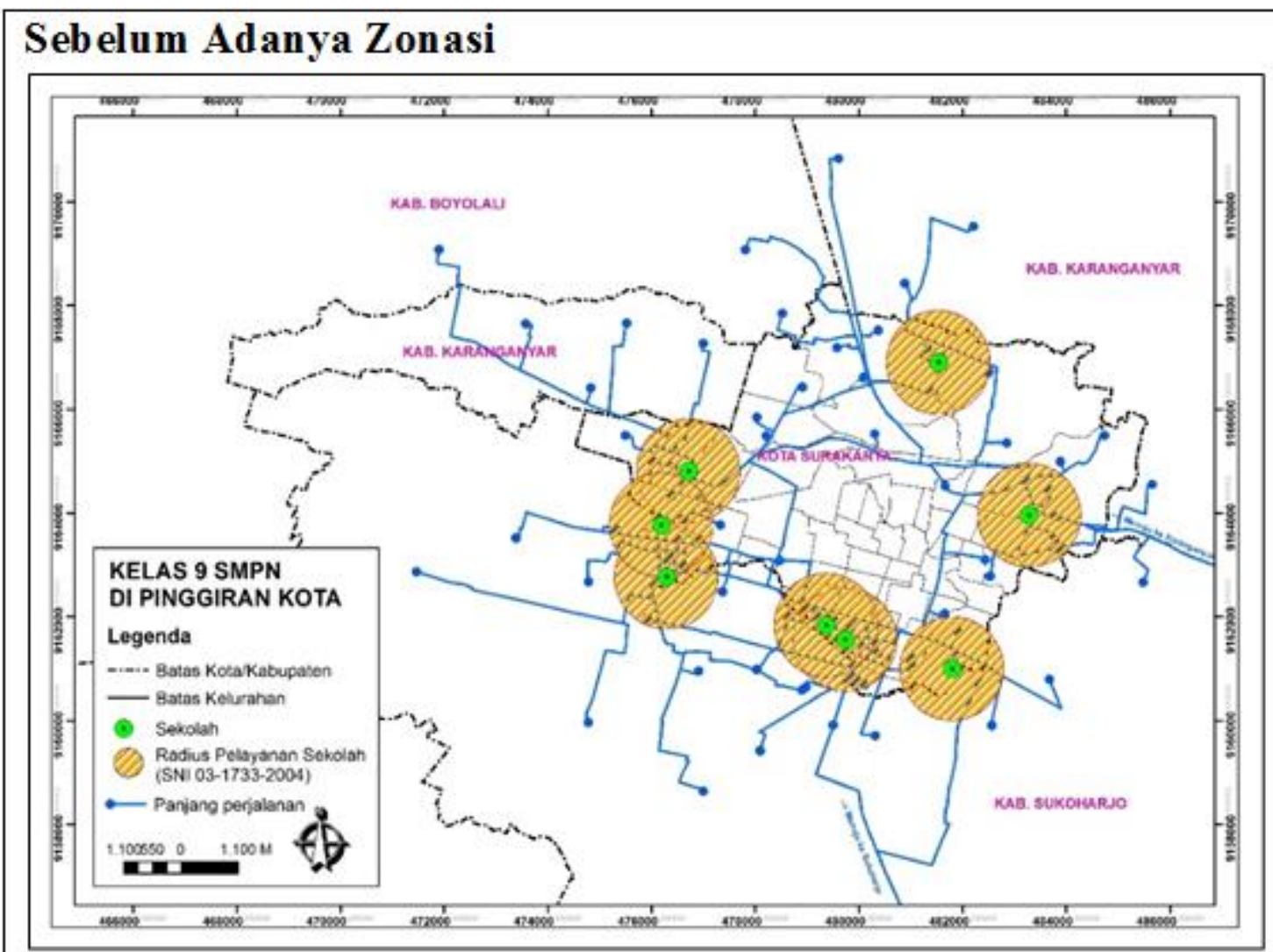

Sesudah Adanya Zonasi

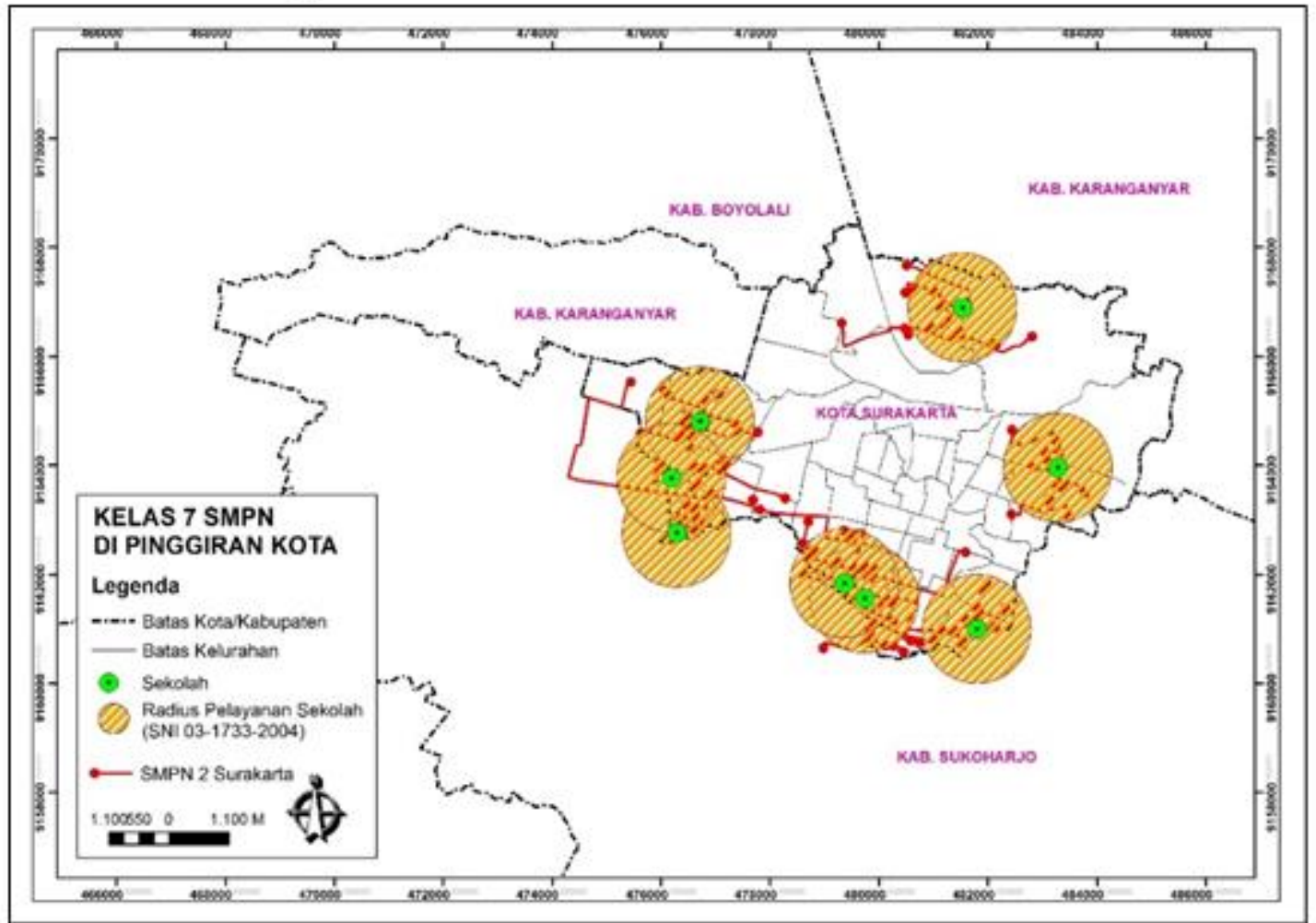

Gambar 4. Perbandingan Jangkauan Pelayanan Fasilitas Pendidikan pada Saat Sebelum dan Sesudah Adanya Kebijakan Zonasi Layanan Pendidikan di Sekolah Pinggiran Kota. 


\section{Analisis Crosstab pada Saat Sebelum dan Sesudah Adanya Kebijakan Zonasi Layanan Pendidikan}

Ada tidaknya hubungan secara statistik antara variabel bebas dengan pemilihan moda transportasi pada sampel siswa kelas 9 diketahui dengan melakukan analisis crosstab. Berdasarkan hasil analisis crosstab pada sampel siswa kelas 9 (Tabel 3), variabel waktu perjalanan, biaya perjalanan, jarak tempuh perjalanan, jenis kelamin, besarnya uang saku, keandalan angkutan umum, keamanan angkutan umum, dan arahan orang tua secara statistik berhubungan dengan pemilihan moda.

Berdasarkan hasil analisis crosstab pada sampel siswa kelas 7 (Tabel 4), terdapat variabel bebas yang secara statistik berhubungan dengan pemilihan moda yaitu variabel biaya perjalanan, ketersediaan angkutan umum, kemudahan akses angkutan online, keandalan angkutan online, ketersediaan jalur pejalan kaki, keamanan jalur sepeda, dan ketersediaan marka pembatas jalur pejalan kaki.

Berdasarkan perbandingan faktor-faktor yang memengaruhi pemilihan moda transportasi siswa pada saat sebelum dan sesudah kebijakan zonasi layanan pendidikan (Tabel 5), faktor yang memengaruhi pemilihan moda transportasi siswa pada saat sebelum adanya kebijakan zonasi adalah waktu perjalanan, biaya perjalanan, jarak tempuh perjalanan, jenis kelamin, besarnya uang saku, keandalan angkutan umum, keamanan angkutan umum, dan arahan orang tua. Sedangkan, pada saat sesudah adanya kebijakan zonasi, faktor yang memengaruhi pemilihan moda transportasi siswa antara lain biaya perjalanan, ketersediaan angkutan umum, kemudahan akses angkutan online, keandalan angkutan online, ketersediaan jalur pejalan kaki, keamanan jalur sepeda, dan ketersediaan marka pembatas jalur pejalan kaki.

\section{E. Analisis Hasil Wawancara}

Dari hasil wawancara yang dilakukan, didapatkan konfirmasi terhadap hasil kuesioner sebagai berikut:

1. ARG menyatakan "Karena bawaan banyak dan lelah, sebenarnya saya suka memakai sepeda tetapi karena banyak kegiatan jadi saya diantar menggunakan motor."

2. CEH diantar orang tua dengan motor. CEH menyatakan "Karena orang tua sanggup untuk mengantar dan memiliki kendaraan sendiri."

3. Y menyatakan "Menggunakan sepeda karena gak ada yang ngantar biar mandiri rumahnya dekat."

4. INA menyatakan "Karena dengan menggunakan sepeda saya merasa senang."

5. NKAA menyatakan "Diantar dengan motor karena berangkat sekolah selalu bareng kakak."

6. NVA menyatakan "Diantar dengan motor, karena lalu lintas ramai dan tidak diizinkan orang tua untuk bersepeda."

7. SOA menyatakan "Diantar dengan mobil, sekalian berangkat kerja sama orang tua."

8. VNC menyatakan "Karena lebih sehat untuk naik sepeda, juga biaya transportasi lebih hemat."

9. RAA menyatakan "Diantar motor, karena motor cenderung lebih cepat dan gesit dalam berhadapan dengan kemacetan lalu lintas yang terjadi setiap hari."

10.ARF menyatakan "Naik ojek online, karena lebih instan". 11.F menyatakan "Naik motor sendiri, karena awalnya untuk

Tabel 3.

Hasil Analisis Crosstab pada Saat Sebelum Kebijakan Zonasi

\begin{tabular}{|c|c|c|c|c|}
\hline No. & Variabel & Pearson Chi-Square & Asymp. Sig. (2-sided) & Keputusan \\
\hline 1 & Waktu perjalanan & 41,747 & 0,000 & H0 ditolak \\
\hline 2 & Biaya perjalanan & 137,582 & 0,000 & H0 ditolak \\
\hline 3 & Jarak tempuh perjalanan & 38,499 & 0,000 & H0 ditolak \\
\hline 4 & Jenis kelamin & 16,693 & 0,019 & H0 ditolak \\
\hline 5 & Usia & 7,675 & 0,362 & H0 diterima \\
\hline 6 & Kepemilikan kendaraan orang tua & - & - & - \\
\hline 7 & Pekerjaan orang tua & 44,493 & 0,866 & H0 diterima \\
\hline 8 & Pendapatan orang tua & 18,517 & 0,184 & H0 diterima \\
\hline 9 & Besarnya uang saku & 166,515 & 0,000 & H0 ditolak \\
\hline 10 & Ketersediaan angkutan umum & 9,738 & & \\
\hline 11 & Keandalan angkutan umum & & 0,204 & HO diterima \\
\hline 12 & Kemudahan akses angkutan umum & 26,940 & 0,020 & H0 ditolak \\
\hline 13 & Kemudahan akses angkutan online & 4,926 & 0,669 & H0 diterima \\
\hline 14 & Keandalan angkutan online & 19,155 & 0,159 & HO diterima \\
\hline 15 & Ketersediaan parkir khusus sepeda & 21,007 & 0,101 & H0 diterima \\
\hline 16 & Ketersediaan jalur khusus sepeda & 3,873 & 0,794 & H0 diterima \\
\hline 17 & Ketersediaan trotoar/jalur pejalan kaki & 12,444 & 0,571 & H0 diterima \\
\hline 18 & Kenyamanan angkutan umum & 19,321 & 0,153 & HO diterima \\
\hline 19 & Kenyamanan di jalur sepeda & 12,002 & 0,606 & HO diterima \\
\hline 20 & Kenyamanan jalur pejalan kaki & 17,087 & 0,252 & H0 diterima \\
\hline 21 & Kenyamanan angkutan online & 15,407 & 0,351 & HO diterima \\
\hline 22 & Keamanan di angkutan umum & 23,155 & 0,058 & H0 diterima \\
\hline 23 & Keamanan di jalur pejalan kaki & 31,923 & 0,004 & H0 ditolak \\
\hline 24 & Keamanan di jalur sepeda & 10,802 & 0,702 & H0 diterima \\
\hline 25 & Keamanan di angkutan online & 20,075 & 0,128 & HO diterima \\
\hline 26 & Ketersediaan tempat penyeberangan & 14,277 & 0,429 & H0 diterima \\
\hline 27 & Ketersediaan marka jalur pejalan kaki & 4,964 & 0,664 & HO diterima \\
\hline 28 & Ketersediaan marka jalur sepeda & 9,968 & 0,190 & H0 diterima \\
\hline 29 & Jaminan keselamatan di angkutan umum & 11,793 & 0,108 & H0 diterima \\
\hline 30 & Jaminan keselamatan di angkutan online & 6,915 & 0,438 & H0 diterima \\
\hline 31 & Arahan dari orang tua & 5,448 & 0,605 & Ho diterima \\
\hline 32 & Arahan dari pihak sekolah & 16,166 & 0,024 & H0 ditolak \\
\hline
\end{tabular}


Tabel 4

Hasil Analisis Crosstab pada Saat Sesudah Kebijakan Zonasi

\begin{tabular}{|c|c|c|c|c|}
\hline No. & Variabel & Pearson Chi-Square & Asymp. Sig. (2-sided) & Keputusan \\
\hline 1 & Waktu perjalanan & 8,235 & 0,083 & H0 diterima \\
\hline 2 & Biaya perjalanan & 29,195 & 0,000 & H0 ditolak \\
\hline 3 & Jarak tempuh perjalanan & 0,617 & 0,961 & H0 diterima \\
\hline 4 & Jenis kelamin & 1,240 & 0,871 & $\mathrm{H} 0$ diterima \\
\hline 5 & Usia & 4,878 & 0,300 & H0 diterima \\
\hline 6 & Kepemilikan kendaraan orang tua & 6,544 & 0,162 & H0 diterima \\
\hline 7 & Pekerjaan orang tua & 47,742 & 0,091 & $\mathrm{H} 0$ diterima \\
\hline 8 & Pendapatan orang tua & 11,507 & 0,175 & H0 diterima \\
\hline 9 & Besarnya uang saku & 5,670 & 0,684 & H0 diterima \\
\hline 10 & Ketersediaan angkutan umum & 10,011 & 0,040 & H0 ditolak \\
\hline 11 & Keandalan angkutan umum & 4,976 & 0,760 & H0 diterima \\
\hline 12 & Kemudahan akses angkutan umum & 11,340 & 0,183 & H0 diterima \\
\hline 13 & Kemudahan akses angkutan online & 19,145 & 0,014 & H0 ditolak \\
\hline 14 & Keandalan angkutan online & 16,060 & 0,042 & H0 ditolak \\
\hline 15 & Ketersediaan parkir khusus sepeda & 0,420 & 0,981 & H0 diterima \\
\hline 16 & Ketersediaan jalur khusus sepeda & 13,819 & 0,087 & H0 diterima \\
\hline 17 & Ketersediaan trotoar/jalur pejalan kaki & 22,186 & 0,005 & H0 ditolak \\
\hline 18 & Kenyamanan angkutan umum & 6,180 & 0,627 & H0 diterima \\
\hline 19 & Kenyamanan di jalur sepeda & 10,231 & 0,249 & H0 diterima \\
\hline 20 & Kenyamanan jalur pejalan kaki & 9,265 & 0,320 & H0 diterima \\
\hline 21 & Kenyamanan angkutan online & 5,415 & 0,247 & H0 diterima \\
\hline 22 & Keamanan di angkutan umum & 3,529 & 0,897 & H0 diterima \\
\hline 23 & Keamanan di jalur pejalan kaki & 8,272 & 0,407 & H0 diterima \\
\hline 24 & Keamanan di jalur sepeda & 16,345 & 0,038 & H0 ditolak \\
\hline 25 & Keamanan di angkutan online & 4,416 & 0,818 & H0 diterima \\
\hline 26 & Ketersediaan tempat penyeberangan & 8,507 & 0,075 & H0 diterima \\
\hline 27 & Ketersediaan marka jalur pejalan kaki & 12,383 & 0,015 & H0 ditolak \\
\hline 28 & Ketersediaan marka jalur sepeda & 7,882 & 0,096 & H0 diterima \\
\hline 29 & Jaminan keselamatan di angkutan umum & 2,977 & 0,562 & H0 diterima \\
\hline 30 & Jaminan keselamatan di angkutan online & 4,811 & 0,307 & H0 diterima \\
\hline 31 & Arahan dari orang tua & 5,754 & 0,218 & H0 diterima \\
\hline 32 & Arahan dari pihak sekolah & 5,174 & 0,270 & H0 diterima \\
\hline
\end{tabular}

Tabel 5 .

Perbandingan Faktor Pemilihan Moda pada Saat Sebelum dan Sesudah Kebijakan Zonasi Layanan Pendidikan

\begin{tabular}{ll}
\hline \hline \multicolumn{1}{c}{ Kondisi } & \multicolumn{2}{l}{ Variabel yang berhubungan (Hasil Crosstab) } \\
\hline Sebelum Kebijakan & - Waktu perjalanan \\
Zonasi Layanan & - Biaya perjalanan \\
& - Jarak tempuh perjalanan \\
& - Jenis kelamin \\
& - Kesarnya uang saku \\
& - Keandalan angkutan umum \\
& - Arahanan orang tuatan umum \\
\hline Sesudah Kebijakan & - Biaya perjalanan \\
Zonasi Layanan & - Ketersediaan angkutan umum \\
Pendidikan & Kemudahan akses angkutan online \\
& - Keandalan angkutan online \\
& - Ketersediaan jalur pejalan kaki \\
& - Ketersediaan marka pembatas jalur pejalan \\
& kaki \\
\hline \hline
\end{tabular}

bergaya biar keren, buat latihan juga mau lanjut ke SMK 2, biar cepet, kalau pakai gojek uang nambah".

12.AFW menyatakan "Diantar motor, lebih hemat dan efektif dan bisa diatur sendiri mau berangkat kapan kalau pakai mobil lama dan membuat macet".

13.DYRI menyatakan "Diantar dengan mobil, karena kalau berangkat bareng, sekalian nganter mama kerja dan adek sekolah, ndak cukup kalau naik motor".

14.AA menyatakan "Naik BST, karena tidak ada yang mengantar dan harganya terjangkau".

15.IHA menyatakan "Diantar motor supaya orang tua tidak kawatir belum mempunyai SIM supaya uang saku tidak habis".

16. AB menyatakan "Naik ojol karena orang tua tidak bisa mengantar, lebih simpel dan mudah".

Para siswa sebelum adanya kebijakan zonasi (siswa kelas 9 yaitu RAA, F, AFW, DYRI, AA, IHA, dan AB) mengonfirmasi hasil kuesioner bahwa waktu perjalanan, besarnya uang saku, biaya perjalanan, dan pengaruh orang tua berpengaruh dalam pemilihan moda transportasi menuju sekolah. Sedangkan, siswa sesudah adanya kebijakan zonasi (siswa kelas 7 yaitu VNC) mengonfirmasi hasil kuesioner bahwa biaya perjalanan berpengaruh terhadap pemilihan moda transportasi ke sekolah.

CEH, NKAA, SOA, DYRI, AA, IHA, dan NVA menyatakan adanya pengaruh keluarga dalam menggunakan moda transportasi ke sekolah. Pengaruh dari keluarga termasuk dalam pengaruh lingkungan sosial mikro. Dalam memilih moda transportasi yang digunakan, siswa tidak menentukan sendiri tetapi ada pengaruh dari lingkungan terdekatnya. F, ARG, VNC, dan Y menyatakan adanya motivasi yaitu kebutuhan aktualisasi diri. AFW, AB, RAA, 
ARF, dan INA menyatakan persepsi terhadap moda tertentu yang melibatkan proses kognitif (melibatkan pikiran) dan afeksi (melibatkan perasaan). Siswa-siswa ini, dalam menentukan pilihan moda transportasi yang digunakan, dipengaruhi preferensi yang berasal dari internal individu dengan melalui tahapan kognitif dan afeksi.

Hasil wawancara mengonfirmasi hasil kuesioner bahwa jarak, biaya perjalanan, waktu perjalanan, dan kemudahan akses angkutan online berpengaruh terhadap preferensi pemilihan moda transportasi siswa. Berdasarkan dari hasil wawancara siswa, diketahui bahwa preferensi pemilihan moda transportasi siswa juga dipengaruhi oleh preferensi individu dan pengaruh lingkungan sosial. Perilaku siswa menggunakan moda transportasi menuju ke sekolah muncul karena adanya tahapan kognitif dan afeksi pada siswa. Sedangkan, pengaruh lingkungan sosial yang dapat memengaruhi berasal dari lingkungan terdekat seperti lingkungan keluarga dan lingkungan kelompok pertemanan di sekolah. Hal ini sesuai dengan teori perilaku konsumen bahwa perilaku konsumen terbentuk karena adanya aspek internal individu (tahapan kognisi dan afeksi) dan adanya aspek eksternal individu (pengaruh lingkungan keluarga, kelompok sosial, dan strata sosial) [3].

F. Faktor-Faktor yang Memengaruhi Preferensi Pemilihan Moda Transportasi Siswa pada Saat Sebelum dan Sesudah Adanya Kebijakan Zonasi Layanan Pendidikan

Preferensi pemilihan moda transportasi siswa SMP di Kota Surakarta dipengaruhi oleh:

1. Faktor internal individu:

- jenis kelamin dan

- motivasi aktualisasi diri.

2. Faktor eksternal individu:

- faktor karakteristik perjalanan (waktu perjalanan, biaya perjalanan, jarak tempuh perjalanan),

- faktor ekonomi (besarnya uang saku),

- faktor ketersediaan sarana transportasi (kemudahan akses angkutan online, keandalan angkutan online, ketersediaan angkutan umum, keandalan angkutan umum),

- faktor ketersediaan prasarana transportasi (ketersediaan jalur pejalan kaki),

- faktor keamanan (keamanan angkutan umum, keamanan jalur sepeda),

- faktor keselamatan (ketersediaan marka pembatas jalur pejalan kaki), dan

- pengaruh lingkungan sosial (arahan orang tua).

\section{KESIMPULAN/RINGKASAN}

Kebijakan zonasi layanan pendidikan tidak berpengaruh terhadap preferensi pemilihan moda transportasi siswa. Berdasarkan hasil analisis keseluruhan sampel siswa saat sebelum kebijakan zonasi layanan pendidikan (siswa kelas 9) dan sesudah kebijakan zonasi layanan pendidikan (siswa kelas 7), sebagian besar siswa diantar orang tua dengan sepeda motor.
Preferensi pemilihan moda transportasi siswa di Kota Surakarta dipengaruhi adanya faktor internal individu dan faktor eksternal individu. Faktor internal individu yang berpengaruh adalah jenis kelamin dan motivasi aktualisasi diri. Faktor eksternal individu yang berpengaruh adalah faktor karakteristik perjalanan (waktu perjalanan, biaya perjalanan, dan jarak tempuh perjalanan), faktor ekonomi (besarnya uang saku), faktor ketersediaan sarana transportasi (kemudahan akses angkutan online, keandalan angkutan online, ketersediaan angkutan umum, dan keandalan angkutan umum), faktor ketersediaan prasarana transportasi (ketersediaan jalur pejalan kaki), faktor keamanan (keamanan angkutan umum \& keamanan jalur sepeda), faktor keselamatan (ketersediaan marka pembatas jalur pejalan kaki), dan pengaruh lingkungan sosial (arahan orang tua).

Dengan adanya kebijakan zonasi layanan pendidikan, jangkauan pelayanan fasilitas pendidikan mendekati standar pelayanan minimal sesuai dengan SNI 03-1733-2004 tentang Tatacara Perencanaan Lingkungan Perumahan di Perkotaan. Kebijakan zonasi layanan pendidikan membuat fasilitas pendidikan dapat diakses pada jarak yang lebih dekat dan dapat ditempuh dengan moda transportasi nonmotor.

Kebijakan zonasi layanan pendidikan dapat meningkatkan kualitas lingkungan karena penggunaan moda transportasi nonmotor dapat mengurangi polusi udara dan kemacetan. Selain itu, ketersediaan zona selamat sekolah dapat memberikan rasa aman kepada pejalan kaki dan pesepeda, dapat mencegah terjadinya kecelakaan, dan menjamin keselamatan anak di sekolah. Sehingga, kebijakan zonasi layanan pendidikan dapat mendukung terwujudnya kota layak huni.

Saran untuk pemerintah:

1. Adanya temuan faktor preferensi internal individu dan pengaruh lingkungan sosial yang memengaruhi pemilihan moda transportasi perlu mendapat perhatian terkait penyediaan transportasi di Kota Surakarta. Di dalam pengambilan kebijakan publik, pemerintah perlu memperhatikan faktor preferensi pribadi/individu dan preferensi kelompok sosial. Perlu dilakukan forum diskusi publik dalam proses perencanaan kebijakan.

2. Pemerintah perlu melakukan peningkatan kualitas sarana prasarana transportasi jarak pendek seperti jalur sepeda dan jalur pejalan kaki. Selain itu, upaya untuk mewujudkan kota layak huni dapat dilakukan dengan memberikan rasa aman pada pejalan kaki dan pesepeda. Pemerintah perlu menyediakan zona selamat sekolah untuk mencegah terjadinya kecelakaan dan menjamin keselamatan siswa di sekolah. Pemerintah Kota Surakarta dapat bekerja sama dengan kepolisian dan pihak sekolah untuk meningkatkan sosialisasi terkait zona selamat sekolah, tertib berlalu lintas, serta program keselamatan lalu lintas angkutan jalan.

3. Pihak sekolah perlu bekerjasama dengan kepolisian untuk melakukan monitoring dan penegakan aturan dengan pemberian sanksi terhadap siswa yang menggunakan sepeda motor sendiri ke sekolah. Pihak sekolah juga perlu menggalakkan program bike to school untuk 
meningkatkan kesadaraan siswa agar menggunakan transportasi nonmotor menuju sekolah.

4. Untuk meningkatkan aksesibilitas sebagai upaya mewujudkan kota layak huni, Pemerintah Kota Surakarta perlu melakukan evaluasi terhadap layanan angkutan umum yang ada dan perlu menyediakan angkutan umum atau bus sekolah yang menjangkau fasilitas-fasilitas pendidikan.

Saran untuk penelitian selanjutnya:

1. Perlu dilakukan penelitian mendalam terkait evaluasi jangkauan layanan pendidikan di Kota Surakarta dengan kebijakan zonasi layanan pendidikan secara spasial dengan mempertimbangkan persebaran lokasi sekolah, daya tampung sekolah, persebaran kawasan permukiman, dan kepadatan penduduk.

2. Perlu dilakukan penelitian lebih lanjut terkait pengaruh faktor preferensi pribadi/individu dan preferensi kelompok sosial terhadap preferensi pemilihan moda transportasi dengan pendekatan psikologis.

3. Pengaruh lingkungan sosial (keluarga) mempunyai peran yang dominan dalam pemilihan moda transportasi siswa SMP di Kota Surakarta. Hal ini berkaitan dengan usia siswa SMP yang belum cukup umur untuk menggunakan kendaraan bermotor sendiri karena belum bisa mendapatkan SIM sehingga dalam melakukan perjalanan ke sekolah masih bergantung kepada orang tua. Perlu dilakukan penelitian lanjutan terkait preferensi orang tua dalam pemilihan moda transportasi bagi anak-anak ke sekolah.

4. Metode yang digunakan dalam penelitian ini kurang mampu dalam menjelaskan bobot faktor yang dominan memengaruhi pemilihan moda. Perlu dilakukan penelitian lebih lanjut dengan pengukuran preferensi menggunakan skala likert untuk mengetahui bobot faktor yang dominan.

5. Perlu dilakukan penelitian lebih lanjut menggunakan metode analisis kualitatif dengan jumlah narasumber yang lebih banyak guna keakuratan hasil.

6. Pada kondisi di daerah lain dengan acuan kebijakan yang berbeda di masing-masing daerah, dapat berbeda pula persentase kuota zonasi yang ditetapkan. Perlu dilakukan penelitian lebih lanjut untuk mengetahui dampak kebijakan zonasi layanan pendidikan di daerah lain dengan persentase kuota zonasi yang berbeda.

\section{UCAPAN TERIMA KASIH}

Penulis mengucapkan terima kasih kepada Pusbindiklatren Bappenas yang telah memberikan kesempatan dan dukungan finansial kepada penulis. Penulis juga mengucapkan terimakasih kepada seluruh civitas akademika Universitas Gadjah Mada, Pemerintah Kota Surakarta dan semua pihak yang tidak dapat penulis sampaikan satu persatu yang telah membantu penulis hingga terselesaikannya penelitian ini.

\section{DAFTAR PUSTAKA}

[1] BSN (2004). Tata Cara Perencanaan Lingkungan Perumahan di Perkotaan, SNI-03-1733-2004. 24-26.

[2] Bungin, B. (2018). Metodologi Penelitian Kuantitaif. Depok: Prenadamedia Group. 114-115.

[3] Dwiastuti, R., Shinta, A., \& Isaskar, R. (2012). Ilmu Perilaku Konsumen. Malang: Universitas Brawijaya Press (UB Press). 29-118.

[4] Hanifah, L. N., \& Wahyudi, T. N. (2019). Peranan Sekolah Kawasan Berbasis Sistem Zonasi Sekolah dalam Pembentukan Karakter Siswa di Era Milenial (Studi Kasus di SMA Negeri 2 Wonogiri). Paper presented at the Seminar Nasional Pendidikan Pengembangan Kualitas Pembelajaran Era Generasi Milenial.

[5] Khaerunnisa, R. (2017). Peran Lembaga Ombudsman Daerah Istimewa Yogyakarta dalam Pengawasan Penyelenggaraan Penerimaan Peserta Didik Baru (PPDB) Sekolah Menengah Atas (SMA) Tahun Pelajaran 2017/2018 Di DIY. (Skripsi), Universitas Muhammadiyah Yogyakarta, Yogyakarta.

[6] Khisty, C. J., \& Lall, B. K. (2005). Dasar-Dasar Rekayasa Transportasi. Jakarta: Erlangga. 1-23.

[7] Lestari, H. A., \& Rosdiana, W. (2018). Implementasi Kebijakan Penerimaan Peserta Didik Baru (PPDB) di SMA Negeri 4 Kota Madiun Tahun 2017. (Skripsi), Universitas Negeri Surabaya, Surabaya.

[8] Metcalf, G. (2002). The Path to a Livable City. San Francisco: Transportation for a Livable City. 4-6.

[9] Naibaho, A. R. (2018). Implementasi Kebijakan Penerimaan Peserta Didik Baru (PPDB) Online Tingkat Sekolah Menengah Atas di Dinas Pendidikan Provinsi Sumatera Utara. (Skripsi), Universitas Sumatera Utara, Medan.

[10] Nurjanah. (2019). Implementasi Sistem Zonasi dalam Menjamin Pemerataan Pendidikan pada Masyarakat Pedesaan (Penelitian di Desa Patengan Kecamatan Rancabali Kabupaten Bandung). (Skripsi), Universitas Islam Negeri Sunan Gunung Djati Bandung, Bandung.

[11] Perdana, N. S. (2019). Implementasi PPDB Zonasi dalam Upaya Pemerataan Akses dan Mutu Pendidikan. Jurnal Pendidikan Glasser, 3(1), 78-92.

[12] Pratiwi, A. A. A. I., \& Layang, I. W. B. S. (2019). Bentuk-Bentuk Maladministrasi Pendidikan pada Penerimaan Peserta Didik Baru Tahun 2018 di Kota Denpasar. Jurnal Kertha Negara, 7(2), 1-13.

[13] Purwanti, D., Irawati, I., \& Adiwisastra, J. (2019). Efektivitas Kebijakan Penerimaan Peserta Didik Baru Sistem Zonasi Bagi Siswa Rawan Melanjutkan Pendidikan. Jurnal GOVERNANSI, 5(1), 1-7.

[14] Safarah, A. A., \& Wibowo, U. B. (2018). Program Zonasi di Sekolah Dasar sebagai Upaya Pemerataan Kualitas Pendidikan di Indonesia. Lentera Pendidikan, 21(2), 206-213.

[15] Tamin, O. Z. (2008). Perencanaan, Pemodelan, \& Rekayasa Transportasi. Bandung: Penerbit ITB. 388-433.

[16] Ulfi, N. F. Z. (2019). Implementasi Permendikbud Nomor 17 Tahun 2017 tentang Penerimaan Peserta Didik Baru (PPDB) di Kabupaten Bantul Tahun 2018. (Skripsi), Universitas Muhammadiyah Yogyakarta, Yogyakarta.

[17] Vahrezi, M. O. (2019). Efektivitas Peraturan Menteri Pendidikan dan Kebudayaan Nomor 14 Tahun 2018 tentang Sistem Zonasi. (Skripsi), Universitas Islam Negeri Sunan Kalijaga Yogyakarta, Yogyakarta.

[18] Viptri, I. S. (2019). Konflik Penerapan Sistem Zonasi Penerimaan Peserta Didik Baru 2018 (Studi Kasus pada SMPN 11 Medan). (Skripsi), Universitas Sumatera Utara, Medan.

[19] Wiseka, S. A., Yuniaristanto, \& Hisjam, M. (2018). Evaluasi Kapasitas dan Jangkauan Pelayanan Fasilitas Pendidikan Sekolah Menengah Pertama dan Madrasah Tsanawiyah di Kota Surakarta. Media Ilmiah Teknik Industri 17(1), 71-77.

[20] Wulandari, D., Hasyim, A., \& Nurmalisa, Y. (2018). Pengaruh Penerimaan Peserta Didik Baru Melalui Sistem Zonasi Terhadap Prestasi Belajar Siswa. Jurnal Kultur Demokrasi, 5(9). 